\title{
ANALISIS PAD (PENDAPATAN ASLI DAERAH) TERHADAP KESEJAHTERAAN MASYARAKAT KABUPATEN LAMONGAN PERIODE TAHUN 2010-2015
}

\author{
)*Abid Muhtarom \\ Fakultas Ekonomi \\ Universitas Islam Lamongan
}

\begin{abstract}
ABSTRAK
Otonomi Daerah terjadi melalui proses penyerahan sejumlah kekuasaan / kewenangan dari Pemerintah Pusat ke Pemerintah Daerah dengan banyak faktor pendukung. Kesejahteraan masyarakat Kabupaten lamongan menjadi tolak ukur dari keberhasilan suatu daerah dalam menjalankan otonomi daerah khususnya Kabupaten lamongan. Peran PAD (Pendapatan asli Daerah) menjadi suatu hal yang wajib dilakukan oleh semua daerah tidak hanya di kabupaten Lamongan. Namun dalam penelitian ini PAD Kabupaten Lamongan menjadi perioritas Utama dalam penelitian. Adanya beberapa sumber pendapatan Kabupaten lamongan yang menjadi penunjang PAD (Pendapatan Asli Daerah) yang dilaksanakan pengelolanya oleh BUMD (Badan Usaha Milik Daerah) yaitu: PD.BPR Bank Daerah Lamongan, PD.Pasar, PDAM Lamongan, dan PD.Aneka Usaha Lamongan Jaya.

Penelitan ini menggunakan penelitian eksplanatori, yaitu hasil yang diperoleh dalam penelitian ini diharapkan dapat memberikan penjelasan tentang bagaimana Analisis PAD (Pendapatan Asli Daerah) Terhadap Kesejahteraan Masyarakat Kabupaten Lamongan (Husaini, 2008:5).

Dari analisis dapat kita lihat bahwa tidak singnifikan antara Pendapatan Asli Daerah dengan Kesejahteraan Masyarakat Kabupaten Lamongan disebabkan karena jumlah PAD (Pendapatan Asli Daerah) yang terus naik namun tidak diikuti oleh Kesejahteraan Masyarakat yang diindikasikan oleh IPM (Index Pembangunan Manusia) yang tidak stabil bahkan beranjak naik. Angka Harapan hidup yang cenderung tetap setiap tahunnya, Index pendidikan yang terus naik 2010-2014 tetapi tidak cukup signifikan dan besar. Hingga index daya beli masyarakat Lamongan yang yang cenderung naik namun tidak terlalu besar. Menjadikan variabel penelitian tidak singnifikan.
\end{abstract}

Kata kunci: Pendapatan Asli Daerah (PAD) dan Kesejahteraan Masyarakat Lamongan

\section{PENDAHULUAN}

Otonomi Daerah terjadi melalui proses penyerahan sejumlah kekuasaan / kewenangan dari Pemerintah Pusat ke Pemerintah Daerah dengan banyak faktor pendukung. Sumber Pembiayaan Daerah atau PAD (Pendapatan Asli Daerah) komponen utamanya berasal dari komponen pajak Daerah dan Retribusi Daerah. SKPKD (Satuan Kerja Pengelola Keuangan Daerah) adalah kontruksi keuangan daerah yang memiliki fungsi SKPD (Satuan Kerja Perangkat Daerah) dan fungsi Pemerintahan Daerah, maka sistem akuntansi pemerintahan harus mencakup kedua sistem tersebut. Dalam pelaksanaan di lapangan, sistem akuntansi Pemerintahan Daerah tersebut dilaksanakan oleh fungsi akuntansi SKPKD. Akuntansi realisasi pendapatan SKPKD harus didukung dengan bukti-bukti sah berupa SKP Daerah, Tanda bukti pembayaran, STS (Surat Tanda Setoran) dan bukti-bukti yang sah lainnya. Disisi lain otonomi juga sebagai tantangan bagi Pemerintah Daerah dalam mengurangi ketergantungan kepada Pemerintah Pusat, dan mempercepat peningkatan kesejahteraan masyarakat.

Peningkatan Pendapatan Asli Daerah (PAD) mutlak harus dilakukan oleh Pemerintah Daerah agar mampu untuk membiayai kebutuhannya sendiri, sehingga 
ketergantungan Pemerintah Daerah kepada Pemerintah Pusat semakin berkurang dan pada akhirnya daerah dapat mandiri. Dalam Undang-Undang Nomor 33 Tahun 2004 tentang perimbangan keuangan antara pemerintah pusat dan pemerintah daerah, melalui pajak daerah dan Rentrebusi daerah.

Hasil pengelolaan kekayaan milik daerah yang dipisahkan merupakan penerimaan daerah yang berasal dari pengelolaan kekayaan daerah yang dipisahkan. Undang-undang nomor 33 tahun 2004 mengklasifikasikan jenis hasil pengelolaan kekayaan daerah yang dipisahkan, dirinci menurut menurut objek pendapatan yang mencakup bagian laba atas penyertaan modal pada perusahaan milik daerah/BUMD, bagian laba atas penyertaan modal pada perusahaan milik negara/BUMN dan bagian laba atas penyertaan modal pada perusahaan milik swasta maupun kelompok masyarakat.

Undang-Undang Nomor 33 Tahun 2004 menjelaskan Pendapatan Asli Daerah yang sah, disediakan untuk menganggarkan penerimaan daerah yang tidak termasuk dalam jenis pajak dan hasil pengelolaan kekayaan daerah yang dipisahkan. Pendapatan ini juga merupakan penerimaan daerah yang berasal dari lain-lain milik pemerintah daerah. Undang-undang nomor 33 tahun 2004 mengklasifikasikan yang termasuk dalam pendapatan asli daerah yang sah meliputi: (a) Hasil penjualan kekayaan daerah yang tidak dipisahkan. (b) Jasa giro.(c) Pendapatan bunga.(d)Keuntungan adalah nilai tukar rupiah terhadap mata uang asing. (e) Komisi, potongan, ataupun bentuk lain sebagai akibat dari penjualan, pengadaaan barang ataupun jasa oleh pemerintah.

Kesejahteraan

masyarakat

Kabupaten lamongan menjadi tolak ukur dari keberhasilan suatu daerah dalam menjalankan otonomi daerah khususnya Kabupaten lamongan. Peran PAD (Pendapatan asli Daerah) menjadi suatu hal yang wajib dilakukan oleh semua daerah tidak hanya di kabupaten Lamongan.
Namun dalam penelitian ini PAD Kabupaten Lamongan menjadi perioritas Utama dalam penelitian. Adanya beberapa sumber pendapatan Kabupaten lamongan yang menjadi penunjang PAD (Pendapatan Asli Daerah) yang dilaksanakan pengelolanya oleh BUMD (Badan Usaha Milik Daerah) yaitu: PD.BPR Bank Daerah Lamongan, PD.Pasar, PDAM Lamongan, dan PD.Aneka Usaha Lamongan Jaya.

Maka dari itu peneliti membuat penelitian dengan judul "ANALISIS PAD (PENDAPATAN ASLI DAERAH) TERHADAP KESEJAHTERAAN MASYARAKAT KABUPATEN LAMONGAN PERIODE TAHUN 20102015"

\section{LANDASAN TEORI \\ 1. PENDAPATAN ASLI DAERAH}

Pendapatan Asli Daerah (PAD) adalah salah satu sumber penerimaan daerah yang mendukung kemampuan keuangan daerah. Pengertian Pendapatan Asli Daerah menurut Undang-Undang no.28 Tahun 2009 yaitu sumber keuangan daerah yang digali dari wilayah daerah yang bersangkutan yang terdiri dari hasil pajak daerah, hasil retribusi daerah, hasil pengelolaan kekayaan daerah yang dipisahkan dan lain-lain pendapatan asli daerah yang sah.

Menurut Nurcholis (2007 : 182) pendapatan asli daerah adalah pendapatan yang diperoleh daerah dari penerimaan pajak daerah, retribusi daerah, laba perusahaan daerah dan lain-lain yang sah. Pendapatan Daerah adalah semua hak daerah yang diakui sebagai penambah nilai kekayaan bersih dalam periode anggaran tertentu (UU No.32 Tahun 2004 tentang pemerintahan daerah), pendapatan daerah berasal dari dana perimbangan pusat dan daerah juga berasal dari daerah itu sendiri yakni 
pendapatan asli daerah serta lainlain pendapatan yang sah.

Menurut Mardiasmo (2002: 132), Pendapatan Asli Daerah (PAD) adalah penerimaan daerah dari sektor pajak daerah, retribusi daerah, hasil perusahaan milik daerah, hasil pengelolaan kekayaan daerah yang dipisahkan, dan lainlain Pendapatan Asli Daerah (PAD) yang sah. Kewenangan untuk memberdayakan sumber keuangan sendiri dilakukan dalam wadah Pendapatan Asli Daerah (PAD) yang sumber utamanya adalah pajak daerah dan retribusi daerah. Idealnya suatu perimbangan keuangan pusat dan daerah terjadi apabila setiap tingkat pemerintahan bebas dalam bidang keuangan untuk membiayai pelaksanaan tugas dan wewenang masing-masing. Artinya Pendapatan Asli Daerah (PAD) menjadi sumber pendapatan utama atau dominan, sementara subsidi atau transfer dari tingkat pemerintah pusat merupakan sumber penerimaan pendukung atau tambahan yang peranannya tidak dominan. Pendapatan Asli Daerah (PAD) merupakan salah satu sumber pembiayaan pemerintahan daerah yang peranannya sangat tergantung kemampuan dan kemauan daerah dalam menggali potensi yang ada di daerah.

Perimbangan keuangan pemerintah pusat dan daerah adalah sistem pembagian keuangan yang adil, proporsional, demokratis, transparan dan bertanggungjawab dalam rangka pendanaan penyelenggaraan desentralisasi, dengan mempertimbangkan potensi, kondisi dan kebutuhan daerah serta besaran penyelenggaraan dekonsentrasi dan tugas pembatuan (UU no.32 Tahun 2004).

Pendapatan Asli Daerah adalah penerimaan yang diperoleh dari sumber-sumber dalam wilayahnya sendiri yang dipungut berdasarkan peraturan daerah yang sesuai dengan peraturan perundangundangan yang berlaku yang terdiri atas:

1) Hasil pajak daerah yaitu pungutan yang dilakukan oleh pemerintah daerah kepada semua objek pajak, seperti orang / badan, benda bergerak / tidak bergerak.

2) Hasil retribusi daerah, yaitu pungutan yang dilakukan sehubungan dengan suatu jasa/fasilitas yang berlaku oleh pemerintah daerah secara langsung dan nyata.

3) Hasil perusahaan milik daerah dan hasil pengelolaan kekayaan daerah yang dipisahkan antara lain laba dividen, penjualan saham milik daerah.

4) Lain-lain pendapatan asli daerah yang sah antara lain hasil penjualan aset tetap dan jasa giro (Sirozujilam dan Mahalli, 2011).

$$
\text { Pendapatan Asli Daerah }
$$

(PAD) yang tinggi belum merupakan jaminan tingginya pendapatan masyarakat di suatu daerah (regional income). Namun demikian, tingginya PAD dapat menjadi sumberdaya yang sangat penting bagi pemerintah daerah di dalam pengembangan wilayah termasuk dalam peningkatan pendapatan masyarakatnya (Rustiadi, Ghifari, Suradinata, Wijanarko, Supranto, Karmaji, Oyong, Nurbaya dan Martha, 2010). Perolehan PAD diperlukan manajemen pemanfaatan dana yang mampu digunakan semaksimal mungkin bagi kemakmuran masyarakat yang sebesar-besarnya melalui program-program dan kegiatan-kegiatan yang diluncurkan pemerintah daerah tersebut (Susanto, Ghifari, Suradinata, 
Wijanarko, Supranto, Karmaji, Oyong, Nurbaya dan Martha, 2010). Adapun sumber-sumber pendapatan asli daerah menurut Undang-Undang RI No.32 Tahun 2004 yaitu :

1) PAD yang terdiri dari :

a. Hasil pajak daerah yaitu pungutan daerah menurut peraturan yang ditetapkan oleh daerah untuk pembiayaan rumah tangganya sebagai badan hukum publik. Pajak daerah sebagai pungutan yang dilakukan pemerintah daerah yang hasilnya digunakan untuk pengeluaran umum yang balas jasanya tidak langsung diberikan sedang pelaksanaanya bisa langsung dipaksakan.

b. Hasil retribusi daerah yaitu pungutan yang telah secara sah menjadi pungutan daerah sebagai pembayaran pemakaian atau karena memperoleh jasa pekerjaan, usaha atau milik pemerintah daerah yang bersangkutan. Retribusi daerah mempuyai sifatsifat yaitu pelaksanaanya besrifat ekonomis, ada imbalan langsung walau harus memenuhi persyaratan-persyaratan formil maupun materiil, tetapi ada alternatif untuk mau tidak membayar, merupakan pungutan yang sifatnya budgetatinya tidak menonjol, dalam hal-hal tertentu retribusi daerah adalah pengembalian biaya yang telah dilakukan oleh pemerintah daerah untuk memenuhi permintaan anggota masyarakat. c. Hasil perusahaan milik daerah dan hasil pengelolaan kekayaan daerah yang dipisahkan. Hasil perusahaan milik daerah merupakan pendapatan daerah dari keuntungan bersih perusahaan daerah yang berupa dana pembangunan daerah dan bagian untuk anggaran belanja daerah yang disetor ke kas daerah, baik perusahaan derah yang dipisahkan, sesuai dengan motif pendirian dan pengelolaan maka sifat perubahan daerah adalah suatu kesatuan produksi yang bersifat menambah pendapatan daerah, memberi jasa, menyelenggarakan

kemanfaatan umum dan memperkembengkan perekonomian daerah.

d. Lain-lain pendapatan yang sah ialah pendapatanpendapatan yang tidak termasuk dalam jenis-jenis pajak daerah, restibusi daerah, pendapatan dinasdinas. Lain-lain usaha daerah yang sah mempunyai sifat pembuka bagi pemerintah daerah untuk melakukan kegiatan yang menghasilkan baik berupa materi dalam kegiatan tersebut bertujuan untuk menunjang, melapangkan, dan memantapkan suatu kebijakan daerah disuatu bidang tertentu.

2) Dana perimbangan diperoleh melalui bagian pendapatan daerah dari penerimaan pajak bumi dan bangunan dari pedesaan , perkotaan, 
pertambangan sumber daya alam, dan serta bea perolehan hak atas tanah dan bangunan. Dana perimbangan terdiri atas dana bagi hasil, dana alokasi umum, dan dana alokasi khusus.

3) Lain - lain pendapatan daerah yang sah adalah pendapatan derah dari sumber lain misalnya sumbangan pihak ketiga kepada daerah yang dilaksanakan sesuai dengan peraturan perundang-undangan yang berlaku.

Menurut Abdul Halim "Akuntansi Sektor Publik : akuntansi keuangan Daerah (2013 : 101) Pendapatan Asli Daerah (PAD) merupakan semua penerimaan daerah yang berasal dari sumber ekonomi asli daerah. Kelompok pendapatan Asli Daerah dipisahkan menjadi 4 jenis pendapatan, yaitu sebagai berikut :
a) Pajak Daerah
b) Retribusi Daerah
c) Hasil Pengelolaan kekayaan milik daerah yang dipisahkan
d) Lain-lain PAD yang sah.

\section{IPM (INDEX PEMBANGUNAN MANUSIA)}

Indeks Pembangunan Manusia (IPM) / Human Development Index (HDI) adalah pengukuran perbandingan dari harapan hidup, melek huruf, pendidikan dan standar hidup untuk semua negara seluruh dunia. IPM digunakan untuk mengklasifikasikan apakah sebuah negara adalah negara maju, negara berkembang atau negara terbelakang dan juga untuk mengukur pengaruh dari kebijaksanaan ekonomi terhadap kualitas hidup.(Wikipedia)

a. Sejarah

Indeks ini pada 1990 dikembangkan oleh pemenang nobel India Amartya Sen dan seorang ekonom Pakistan Mahbub ul Haq, serta dibantu oleh Gustav Ranis dari Yale University dan Lord Meghnad Desai dari London School of Economics. Sejak itu indeks ini dipakai oleh Program pembangunan PBB pada laporan IPM tahunannya.

Amartya Sen menggambarkan indeks ini sebagai "pengukuran vulgar" oleh karena batasannya. Indeks ini lebih berfokus pada hal-hal yang lebih sensitif dan berguna daripada hanya sekedar pendapatan perkapita yang selama ini digunakan. Indeks ini juga berguna sebagai jembatan bagi peneliti yang serius untuk mengetahui hal-hal yang lebih terinci dalam membuat laporan pembangunan manusianya.

IPM mengukur pencapaian rata-rata sebuah negara dalam 3 dimensi dasar pembangunan manusia:

a) hidup yang sehat dan panjang umur yang diukur dengan harapan hidup saat kelahiran

b) Pengetahuan yang diukur dengan angka tingkat baca tulis pada orang dewasa (bobotnya dua per tiga) dan kombinasi pendidikan dasar, menengah , atas gross enrollment ratio (bobot satu per tiga).

c) standard kehidupan yang layak diukur dengan logaritma natural dari produk domestik bruto per kapita dalam paritasi daya beli.

Setiap tahun Daftar negara menurut IPM diumumkan berdasarkan penilaian diatas. Pengukuran alternatif lain adalah Indeks Kemiskinan Manusia yang lebih berfokus kepada kemiskinan.

\section{METODELOGI PENELITIAN}

Penelitan ini menggunakan penelitian eksplanatori, yaitu hasil yang diperoleh dalam penelitian ini diharapkan dapat memberikan penjelasan tentang bagaimana Analisis PAD (Pendapatan Asli Daerah) Terhadap Kesejahteraan Masyarakat Kabupaten Lamongan (Husaini, 2008:5). 
Ditinjau dari sifat hubungan antara variabelnya, penelitian ini dirancang sebagai penelitian kausal dimana variabel yang satu dengan yang lain tidak sekedar dijelaskan hubungan korelasinya, lebih dari itu akan didiskripsikan dan dianalisis dengan menggunakan SPSS 20. Sesuai dengan rumusan masalah dan tujuan penelitian, secara hipotesis, diidentifikasikan variabel yang akan diteliti, yaitu : PAD (Pendapatan Asli Daerah) dan Kesejahteraan Masyarakat Kabupaten Lamongan.

\section{PEMBAHASAN}

1. Gambaran Umum PAD ( Pendapatan Asli Daerah)

Pendapatan Asli Daerah (PAD) merupakan semua penerimaan yang diperoleh daerah dari sumber-sumber dalam wilahnya sendiri yang dipungut berdasarkan peraturan daerah sesuai dengan peraturan perundang-undangan yang berlaku (Halim, 2004:96). Sektor pendapatan daerah memegang peranan yang sangat penting, karena melalui sektor ini dapat dilihat sejauh mana suatu daerah dapat membiayai kegiatan pemerintah dan pembangunan daerah. Pendapatan Asli Daerah di Kabupaten Lamongan dapat diperoleh dari BUMD ( Badan Usaha Milik Daerah) Kabupaten Lamongan yang di kelolah oleh Pemerintah Kabupaten Lamongan. Badan Usaha Milik Daerah (BUMD) yang dikelola oleh kabupaten Lamongan adalah di bidang perbankan PD.BPR Bank Daerah Lamongan, bidang jasa lainnya adalah PDAM Kab. Lamongan, bidang Perdagangan ada PD. Pasar dan PD.Aneka Usaha Lamongan Jaya. Berdasarkan tabel akan diketahui bahwa penerimaan khususnya dari Laba BUMD terhadap Pendapatan Asli Daerah (PAD ) tidak selalu mengalami kenaikan juga mengalami penurunan

Berdasarkan hasil penelitian dengan memanfaatkan data sekunder atau dokumen yang didapat dari Dispenda Kabupaten Lamongan dan Perusahaan Daerah yang terkait diketahui realisasi laba BUMD kabupaten Lamongan berikut ini :

Tabel 4.1

Laba Penyertaan BUMD Kabupaten Lamongan tahun 2010 - 2014

\begin{tabular}{|c|c|c|c|c|c|c|}
\hline No & Perusda & $\begin{array}{c}\text { Laba } \\
\text { Th.2010 }\end{array}$ & $\begin{array}{c}\text { Laba } \\
\text { Th.2011 }\end{array}$ & $\begin{array}{c}\text { Laba } \\
\text { Th.2012 }\end{array}$ & $\begin{array}{c}\text { Laba } \\
\text { Th.2013 }\end{array}$ & $\begin{array}{c}\text { Laba } \\
\text { Th.2014 }\end{array}$ \\
\hline 1. & $\begin{array}{l}\text { PD.BPR Bank } \\
\text { Daerah } \\
\text { Lamongan }\end{array}$ & $\begin{array}{r}1.268 .787 .15 \\
8\end{array}$ & 957.699 .976 & $\begin{array}{r}1.022 .293 .54 \\
5\end{array}$ & $\begin{array}{r}1.140 .583 .17 \\
7\end{array}$ & $\begin{array}{r}1.678 .304 .71 \\
5\end{array}$ \\
\hline 2. & PD.Pasar & 0 & 207.699 .303 & 487.308 .807 & 149.591 .500 & 283.193 .069 \\
\hline 3. & $\begin{array}{l}\text { PD.Aneka } \\
\text { Usaha } \\
\text { Lamongan Jaya }\end{array}$ & 155.000 .000 & 155.000 .000 & 155.000 .000 & 180.000 .000 & 180.000 .000 \\
\hline 4. & $\begin{array}{l}\text { PDAM } \\
\text { Lamongan }\end{array}$ & 0 & 0 & 0 & 0 & 0 \\
\hline & Total Laba & $\begin{array}{r}1.423 .787 .15 \\
8\end{array}$ & $\begin{array}{r}1.320 .399 .27 \\
9\end{array}$ & $\begin{array}{r}1.664 .602 .35 \\
2\end{array}$ & $\begin{array}{r}1.470 .174 .67 \\
7\end{array}$ & $\begin{array}{r}2.141 .497 .78 \\
4\end{array}$ \\
\hline
\end{tabular}

Sumber : Dinas Pendapatan Daerah,Dispenda Kabupaten Lamongan 2015 dan Perusahan Daerah. (diolah)

Dari data tabel 4.1 dapat dijelaskan sebagai berikut PD.BPR Bank Daerah Lamongan terdapat laba tahun 2010 sebesar Rp 1.268.787.158 dan laba tersebut turun pada tahun 2011 sebesar Rp
957.699.976, sedangkan pada tahun 2012 mengalami kenaikan $\mathrm{Rp} 1.022 .293 .545$ dan juga pada tahun 2013 naik sebesar Rp1.140.583.177 dan kenaikan dilanjutkan 
pada tahun 2014 sebesar $\mathrm{Rp}$ 1.678.304.715.

Pada PD. Pasar pada tahun 2010 sebesar 0,00 dan pada tahun 2011 ada pemasukan laba sebesar Rp 207.699.303, sedangkan Tahun 2012 mengalami kenaikan dari tahun sebelumnya sebesar Rp 487.308.807 dan tahun 2013 sebesar Rp 149.591 .500 mengalami penurunan dari tahun 2012. Pada tahun 2014 sebesar Rp 283.193.069 terjadi kenaikan dari tahun 2013.
PD.Aneka Usaha Lamongan Jaya pada tahun 2010 sebesar Rp 155.000.000 dan tahun 2011-2012 laba sama sebesar 155.000.000, sedangkan tahun 2013-2014 juga mengalami kesamaan sebesar $\mathrm{Rp}$ 180.000.000.

Pada PDAM Lamongan selama kurun waktu 2010-2014 tidak mendapatkan Laba sama sekali bahkan tergolong minus.

Tabel 4.2

Target dan Realisasi Laba Penyertaan Modal BUMD Kabupaten Lamongan tahun 2010 2014

\begin{tabular}{cccccr}
\hline NO & TAHUN & $\begin{array}{c}\text { TARGET } \\
(\mathbf{2})\end{array}$ & $\begin{array}{c}\text { REALISASI } \\
\mathbf{( 3 )}\end{array}$ & $\begin{array}{c}\text { \% } \\
(\mathbf{3 / 2})\end{array}$ & \multicolumn{1}{c}{$\begin{array}{c}\text { LEBIH / } \\
\text { KURANG }\end{array}$} \\
\hline 1. & 2010 & $1.423 .787 .150,00$ & $1.423 .787 .157,88$ & 100,00 & 8,00 \\
2. & 2011 & $14.319 .836 .000,00$ & $13.248 .936 .779,00$ & 92,52 & $1.070 .899 .221,00$ \\
3. & 2012 & $15.414 .601 .500,00$ & $16.040 .602 .352,00$ & 104,06 & $626.000 .852,00$ \\
4. & 2013 & $15.289 .170 .000,00$ & $15.389 .749 .772,00$ & 100,66 & $100.579 .772,00$ \\
5. & 2014 & $16.001 .335 .000,00$ & $16.091 .497 .784,00$ & 100,56 & $90.162 .784,00$ \\
\hline
\end{tabular}

Sumber : Dinas Pendapatan Daerah,Dispenda Kabupaten Lamongan 2015 dan Perusahan Daerah. (diolah)

Pada data tabel 4.2 diatas dapat dilihat bahwa dari target dan realisasi tahun 2010 dapat terpenuhi semua. Namun pada tahun 2011 terdapat kekurangan sebesar 92,52\% dari Target penyertaan modal BUMD.
Tahun 2012 melebihi tagret yang diberikan sebesar 104,06\% dan tahun 2013 juga melebihi target sebesar $100,66 \%$ dimana diikuti tahun 2014 sebesar 100,56\%.

Tabel 4.3

Total PAD Kabupaten Lamongan tahun 2010 - 2014

\begin{tabular}{|ccc|}
\hline No & Tahun & Total PAD \\
\hline 1. & 2010 & $95.244 .807 .228,09$ \\
\hline $\mathbf{2 .}$ & 2011 & $99.545 .629 .500,31$ \\
\hline 3. & 2012 & $129.284 .733 .136,02$ \\
\hline 4. & 2013 & $161.087 .916 .084,90$ \\
\hline 5. & 2014 & $272.193 .207 .652,81$ \\
\hline
\end{tabular}

Sumber : Dinas Pendapatan Daerah,Dispenda Kabupaten Lamongan 2015 dan Perusahan Daerah. (diolah)

Pendapatan Asli Daerah pada tahun 2010 totalnya sebesar $\mathrm{Rp}$ 95.244.807.228,09 dan naik pada tahun 2011 sebesar Rp 99.545.629.500,31. Pada tahu 2012 total PAD Kabupaten
Lamongan Sebesar Rp 129.284.733.136,02 dan tahun 2013 PAD naik sebesar Rp 161.087.916.084,90 dan tahun 2014 PAD Kabupaten Lamongan Naik sebesar Rp 272.193.207.652,81. 
Tabel 4.4

Pertumbuhan Index Pembangunan Manusia indikator Kesejahteraan Masyarakat Kabupaten Lamongan tahun 2010-2014

\begin{tabular}{ccc}
\hline No & Tahun & IPM \\
\hline 1. & 2010 & 4,806 \\
2. & 2011 & 1,24 \\
3. & 2012 & 1,96 \\
4. & 2013 & 20,07 \\
\hline 5. & 2014 & 0,76 \\
\hline
\end{tabular}

Sumber :BPS Jawa Timur. (diolah)

Pertumbuhan Index Pembangunan Manusia Kabupaten Lamongan tahun 2010 sebesar 4,806 \% dan pada tahun 2011 sebesar 1,24\% dan naik pada tahun 2012 sebesar 1,96 \%. Pada tahun 2013 Pertumbuhan Index Pembangunan Manusia Kabupaten Lamongan sebesar 20,07\% dan turun lagi pada tahun 2014 sebesar $0,76 \%$.

2. Analisis Statistik

Metode Regresi sederhana

\section{Correlations}

\begin{tabular}{|c|c|c|c|}
\hline & & PAD & $\begin{array}{l}\text { Keseja } \\
\text { hteraan }\end{array}$ \\
\hline Pearson & PAD & $\begin{array}{r}1,00 \\
0\end{array}$ &,- 040 \\
\hline o & $\begin{array}{l}\text { Keseja } \\
\text { hteraan }\end{array}$ & ,040 & 1,000 \\
\hline $\begin{array}{l}\text { Sig. (1- } \\
\text { tailed) }\end{array}$ & $\begin{array}{l}\text { PAD } \\
\text { Keseja } \\
\text { hteraan }\end{array}$ & , 475 & 475 \\
\hline $\mathrm{N}$ & $\begin{array}{l}\text { Keseja } \\
\text { hteraan }\end{array}$ & 5 & 5 \\
\hline
\end{tabular}

Dari hasil perhitungan didapatkan angka korelasi antara Pendapatan Asli Daerah dengan Kesejahteraan Masyarakat Kabupaten Lamongan sebesar -0,040. Artinya hubungan kedua variabel tersebut sangat lemah tetapi negatif. Korelasi negatif menunjukan bahwa hubungan antara Pendapatan Asli Daerah dengan Kesejahteraan Masyarakat Kabupaten Lamongan tidak searah atau berlawanan.
Dari data dapat dilihat probalitas (sig) sebesar 0,475 yang lebih besar dari 0,05, maka ada hubungan kedua variabel Pendapatan Asli Daerah dengan Kesejahteraan Masyarakat Kabupaten Lamongan tidak singnifikan.

Dari analisis diatas dapat kita lihat bahwa tidak singnifikan antara Pendapatan Asli Daerah dengan Kesejahteraan Masyarakat Kabupaten Lamongan disebabkan karena jumlah PAD (Pendapatan Asli Daerah) yang terus naik namun tidak diikuti oleh Kesejahteraan Masyarakat yang diindikasikan oleh IPM (Index Pembangunan Manusia) yang tidak stabil bahkan beranjak naik. Angka Harapan hidup yang cenderung tetap setiap tahunnya, Index pendidikan yang terus naik 2010-2014 tetapi tidak cukup signifikan dan besar. Hingga index daya beli masyarakat Lamongan yang yang cenderung naik namun tidak terlalu besar. Menjadikan variabel penelitian tidak singnifikan.

\section{KESIMPULAN}

1. Dari hasil perhitungan didapatkan angka korelasi antara Pendapatan Asli Daerah dengan Kesejahteraan Masyarakat Kabupaten Lamongan sebesar -0,040. Artinya hubungan kedua variabel tersebut sangat lemah tetapi negatif. Korelasi negatif menunjukan bahwa hubungan antara Pendapatan Asli Daerah dengan Kesejahteraan Masyarakat Kabupaten Lamongan tidak searah atau berlawanan. 
2. Dari data dapat dilihat probalitas (sig) sebesar 0,475 yang lebih besar dari 0,05, maka ada hubungan kedua variabel Pendapatan Asli Daerah dengan Kesejahteraan Masyarakat Kabupaten Lamongan tidak singnifikan.

3. Dari analisis diatas dapat kita lihat bahwa tidak singnifikan antara Pendapatan Asli Daerah dengan Kesejahteraan Masyarakat Kabupaten Lamongan disebabkan karena jumlah PAD (Pendapatan Asli Daerah) yang terus naik namun tidak diikuti oleh Kesejahteraan Masyarakat yang diindikasikan oleh IPM (Index Pembangunan Manusia) yang tidak stabil bahkan beranjak naik. Angka Harapan hidup yang cenderung tetap setiap tahunnya, Index pendidikan yang terus naik 2010-2014 tetapi tidak cukup signifikan dan besar. Hingga index daya beli masyarakat Lamongan yang yang cenderung naik namun tidak terlalu besar. Menjadikan variabel penelitian tidak singnifikan.

\section{DAFTAR PUSTAKA}

www.BPS.go.id

www. Wikipedia.com

Husaini. 2008. Buku Latihan SPSS

Parametrik. Jakarta: PT Elex

Media Computindo.

Irwan dan Suparmoko,1992. Ekonomika

Pembangunan. Edisi lima,

Yogyakarta: BPFE-Yogyakarta

Boediono,2001. Ekonomi Makro. Yogyakarta: BPFE-Yogyakarta.

Dajan, Anto. 1984. Pengantar Metode Statistik. Jilid 2. Jakarta: LP3ES.

Gujarati, Domoar, 1995. Ekonometrika Dasar. Jakarta: Erlangga.

Undang-undang No.33 tahun 2004 tentang Perimbangan keuangan antara pemerintah pusat dan daerah

Undang-undang RI No.28 tahun 2009 tentang Pajak daerah dan pendapatan daerah
Nurcholis, Hanif, 2007. Teori dan Praktik Pemerintahan dan Otonomi Daerah. Jakarta : Grasindo.

Mardiasmo, 2002. Otonomi dan Manajemen Keuangan Daerah, Yogyakarta : Andi.

Tangkilisan, dan Hessel N.S. 2005, Manajemen Publik, Jakarta : PT.Grassindo

Susanto A.B, Ghifari A.B, Susanto A, Suradinata E, Wijanarko H, Supranto J,

Karmaji, Oyong R, Nurbaya S dan Marth S, 2010, Reinvensi Pembangunan Ekonomi Daerah, Jakarta : Esensi Erlangga Group.

Halim Abdul, Kusufi S.M, 2013, Akuntansi Sektor Publik : Akuntansi Keuangan Daerah, Jakarta : Salemba Empat.

Lilik. 2015. “Analisis Efektivitas PDAM terhadap Peningkatan PAD kabupaten Lamongan" Jurnal tidak dipublikasi litbang lamongan. 